\title{
AN ASSESSMENT OF WALTER RAINE AND HIS SASKATCHEWAN RECORDS
}

\author{
C. STUART HOUSTON, 863 University Drive, Saskatoon, Saskatchewan. S7N 0J8
}

Walter Raine was born in Leeds, England, on 15 September 1861. He emigrated to Toronto, Ontario in 1884 and worked as a lithographic engraver and watercolour artist, for Hough and Harris Co. and later for Howell.

His obsessive life-long hobby and after-hours business was oology. He bought and sold birds' eggs from his home when egg collecting was a more flourishing hobby than stamp collecting and indeed he had one of the largest such businesses in North America. At one time, Raine's collection of 50,000 eggs was the largest in Canada. He won prizes for his egg displays at the Toronto fair, displaying items such as a case of 50 eggs of the Golden Eagle. Raine published accounts of his 1891 and 1893 egg-collecting trips to Saskatchewan, ${ }^{14} 15$ this 1901 records were quoted by John Macoun ${ }^{10} 11^{12}$ and his
1901 photographs were used by Reed. ${ }^{23}$

\section{My Interest in Raine:}

In my 35 years of study of the history of Saskatchewan ornithology, by far the most perplexing problem has been whether to use, or how to use, the records of Walter Raine. Raine certainly made some serious errors in identification, especially in his early years, but I have never been convinced that these justified wholesale rejection of all of his records.

Extreme views have been held. The late James L. Baillie, Jr., of the Royal Ontario Museum of Zoology advised me on 14 August 1947 that any record that had passed through the hands of Walter Raine should be rejected. Baillie in turn had received the following advice regarding Raine in a letter from $P$. A.

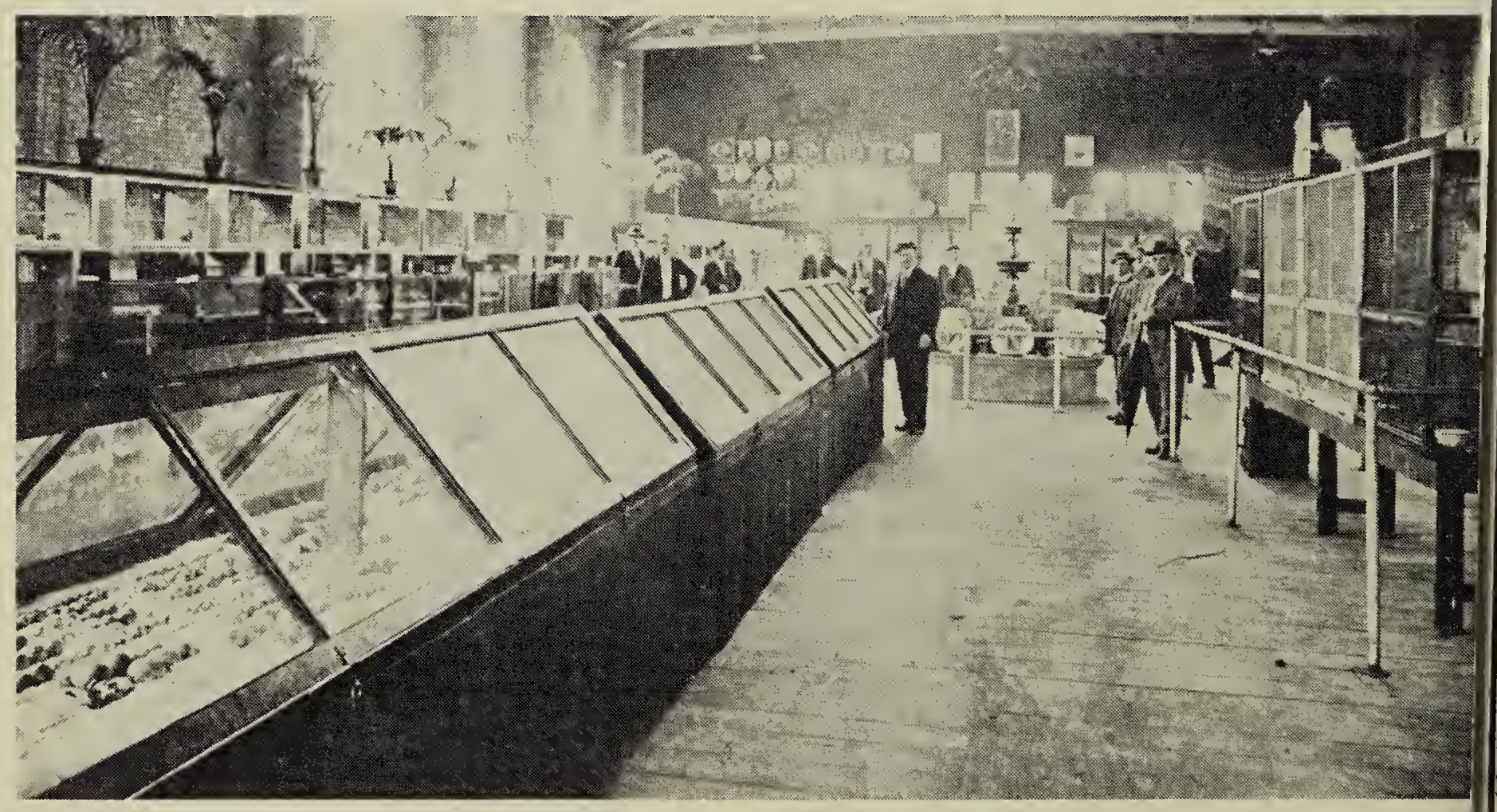

Walter Raine with his display at the Toronto fair (3 large cases of eggs). 


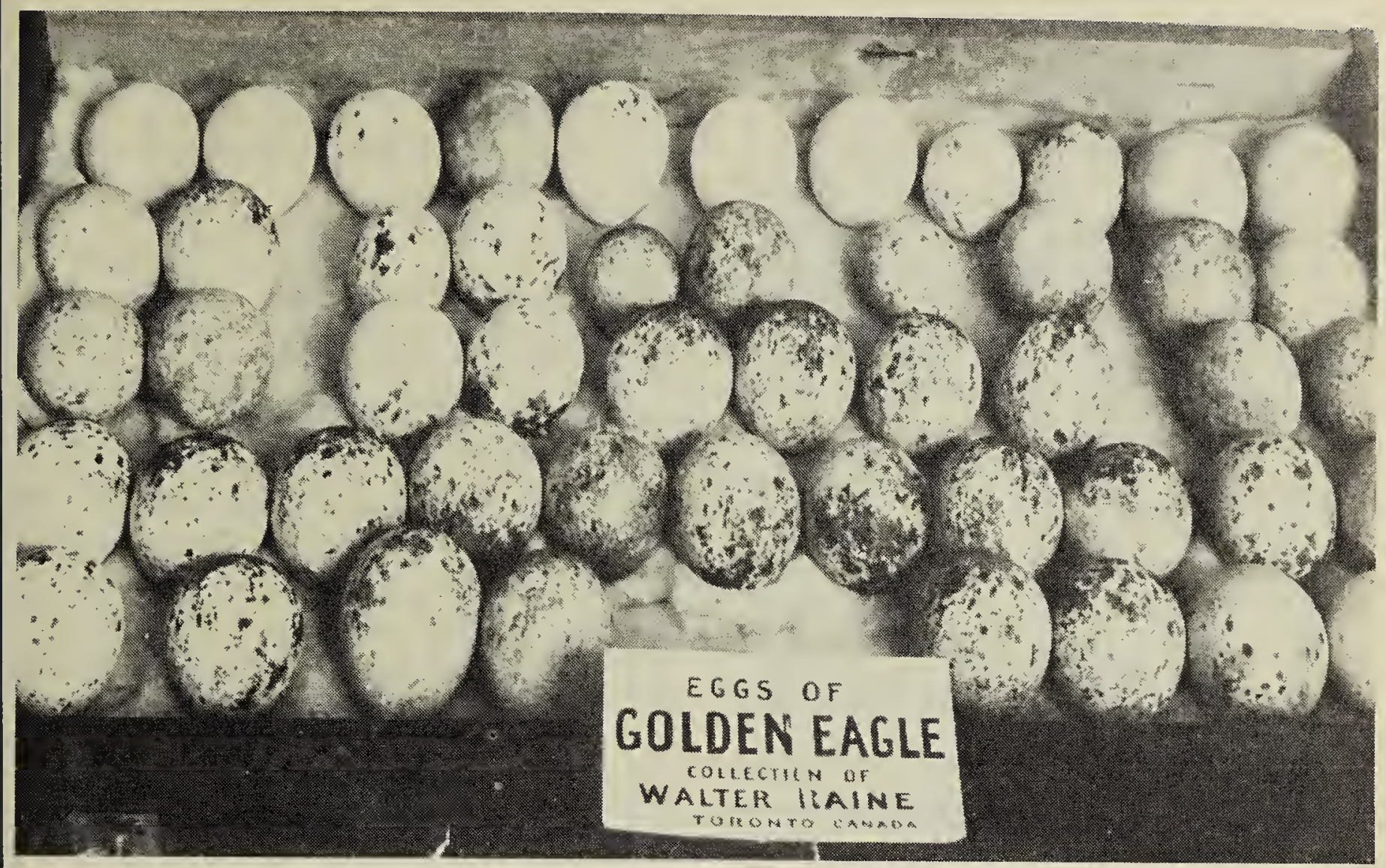

Golden Eagle eggs - display of 50 (about 1910).

\section{Taverner on 19 December 1934:}

"I think we had better disregard everything he ever said or did unless supported by contributory evidence. Have no doubt that the majority of his records are perfectly good but if they are in agreement with our understanding they add nothing to our knowledge and if they are contrary they cannot be relied upon. Either way they are usless. Too bad."

At that time I showed Baillie's letter to Frank Baines, the first Yorkton area naturalist, who vehemently defended Raine's integrity and reported from his personal experience that "Walter Raine was a perfect English gentleman."

Fred and Frank Baines were lads of eight and five years of age when their parents settled in 1883 along the southeast shore of Crescent Lake, 10 miles west of the later site of Saltcoats, Saskatchewan. From 1895 until the turn of the century the Baines boys had been follectors for Walter Raine. Eggs were plown before shipment to Toronto and ften the parent bird was collected for Fertain identification, with Frank making the study skin using arsenic paste. The boys were intensely interested in wildlife and times were hard. They received a little pocket money for their efforts, usually ten cents per skin and a few cents for each egg. ${ }^{6}$

In June 1901, Walter Raine spent at least eight days at Crescent Lake, using the Baines farm as his base. During this visit, Raine obtained beautiful photographs of nests of the Horned Grebe, Sandhill Crane, Marbled Godwit and Upland Sandpiper, which were published in Reed's book in 1904. ${ }^{23}$ John Macoun quoted a number of Raine's sightings made during this visit, when Raine found "close upon thirty nests" of the Swainson's Hawk, each with three eggs..$^{11} 1213$ Between 2 and 5 June 1901, Raine collected at least four sets of eggs of the Merlin, three of which are now in the Field Museum in Chicago and one in the Museum of Vertebrate Zoology at Berkeley, California. ${ }^{7}$ Since this was Raine's only known intensive study area in "northern Assiniboia", there can be little doubt that Crescent Lake was also the locality where Raine 
that year found "about a dozen nests" of the Ferruginous Hawk.

\section{CONTACT WITH RAINE'S FAMILY:}

In September 1977, when I had an hour to spare in the Toronto airport en route from Boston, and after scanning 16 Raine listings in the Toronto telephone directory, I had the temerity to telephone Mrs. Stanley Raine. I had remembered a congratulatory note in the Oologist in 1927 which noted the marriage of Stanley Raine, son and assistant to Walter Raine, to Nermaye Morrison, in Toronto on 2 October 1926. Imagine my surprise when the lady I phoned was indeed the widow of Stanley Raine. Before his death in 1947, Stanley Raine had an engraving business, and both designed and engraved the "wings" that were pinned on the chest of every Canadian airman during the Second World War.

Mrs. Stanley Raine suggested that her niece, Mrs. Marjorie Warren, would be the most useful contact for further information. I next telephoned Mrs.
Warren and was invited to spend an evening at her home during my next visit to Toronto the following month. There I was also able to visit with two of Raine's daughters, Mrs. Ada Heppinstall and Mrs. Alice Stewart, both aunts of Mrs. Warren.

The family supplied biographical information and the photographs used in this article. They loaned me the historic hand-written letter of 30 July 1904 from Evan Thomson of Red Lodge, Alberta, telling Raine of the first three authentic nests ever found of the Solitary Sandpiper. Thomson, one of Raine's collectors, had sent Raine one set of Solitary Sandpiper eggs from a previous year's nest of the American Robin in 1903, but Raine did not publish this momentous information until 1904 when Thomson collected another two sets of eggs from nests of the blackbird and Cedar Waxwing, and a specimen of the adult female Solitary Sandpiper to corrobarate the identification beyond any doubt. ${ }^{21} 22$ When he published his article in the Ottawa Naturalist in October

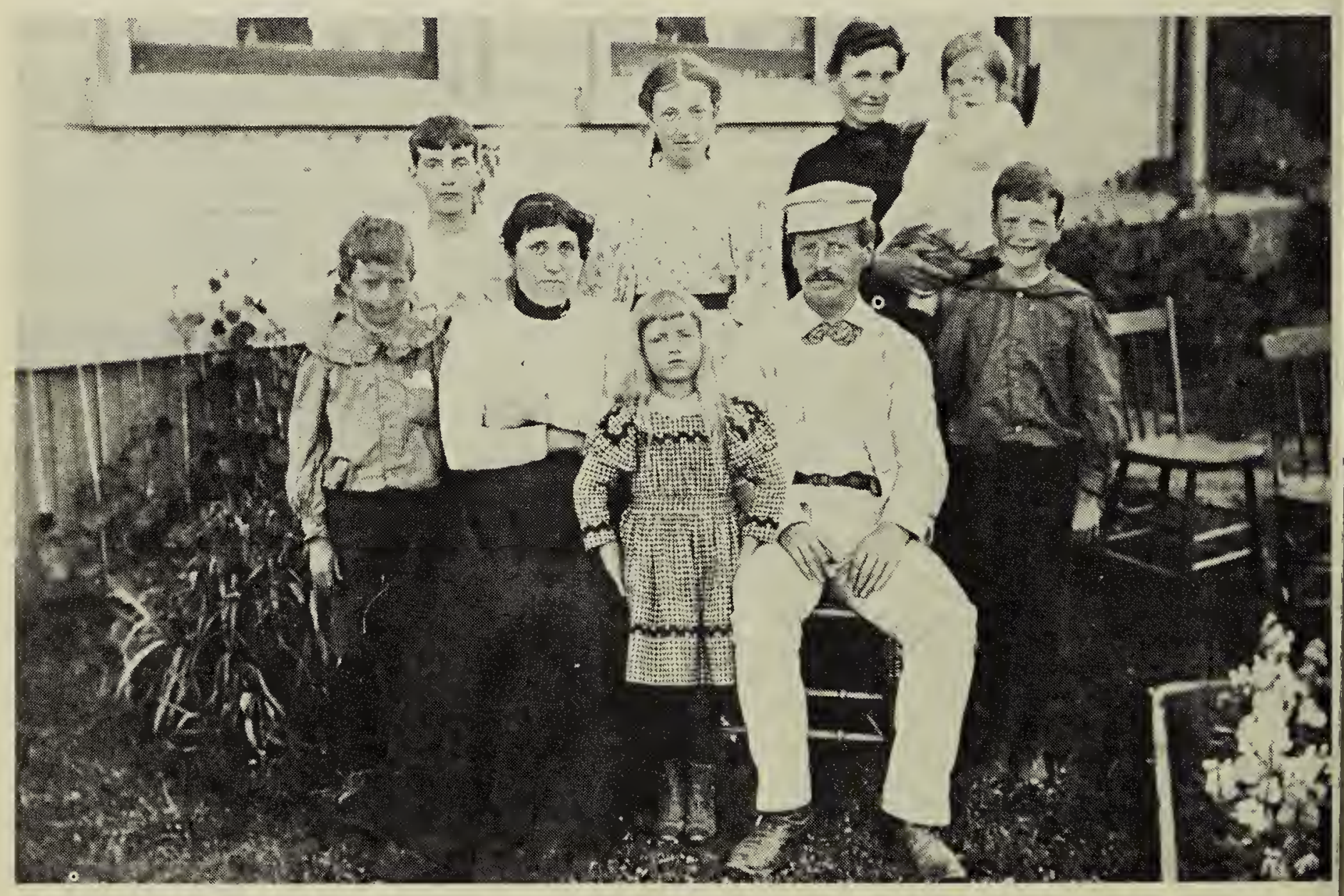


1904, Raine took some liberties in improving Thomson's grammar and punctuation, even though he gave the contents within quotation marks. ${ }^{21}$

The family also loaned me Jourdain's reprint from Ibis of $1907,{ }^{8}$ in which Raine's drawings of four eggs of the Solitary Sandpiper were reproduced. The accompanying dates indicated that Thomson had collected three additional sets on 16 June 1905, 6 June 1906, and 15 June 1906. These eggs had been chosen from 27 eggs of the Solitary Sandpiper that had been measured by Raine, possibly six full sets of four eggs each, and another of three eggs. These three additional Alberta nest records have not been mentioned by most writers since, perhaps because of unfamiliarity with Jourdain's article, and perhaps in part because of coincidental details and dates between the original 1903 nest and one of the 1906 nests.

Mrs. Warren also loaned me the hand-written manuscript of a paper that Walter Raine had presented to the Leeds Naturalist Club in August 1878, the month before his 17 th birthday, and six years before he emigrated to Ontario.

\section{Walter Raine's Work}

IN THE LEEDS AREA, 1877-1883:

The handwritten copy of Raine's talk, 14 pages in length when typed, was a creditable effort for a keen 16-year-old to present to a group of distinguished adults. Raine gave interesting details of his personal observations of 86 species observed within a 10-mile walking distance of Leeds, including the neighbourhoods of Adel, Eccup, Harewood, Roundhay and Shadwell. Raine estimated that 65 species nested regularly; that season he had found 1074 eggs but had taken "not more than 100 ", since he already had most of the others represented in his collection.

To assess the credibility of Raine's paper, I wrote to K. G. Spencer of
Burnley, Lancashire and to John Govett of Trowbridge, Wiltshire, both graduates of Leeds University, and to Arthur Gilpin of Leeds. All three were most helpful, with Gilpin offering detailed comments on the changes in birdlife that have resulted in the more than 100 years since, as most of Raine's old haunts have become urbanized. All three felt that Raine's identifications "rang true", but that there were discrepancies in details concerning a few nests.

Adrian Norris, Assistant Keeper, Natural History, Leeds City Museum, kindly provided me with electrostatic copies of the 17 notes published by Raine in The Naturalist between 1878 and 1882. One of these dealt with Raine's sighting of a polecat, but the other 16 dealt with sightings of rare birds or interesting nests. Norris also copied from the Leeds Archives the appropriate item from the Yorkshire Post and Leeds Mercury which reported the 20 August 1878 meeting of the Leeds Naturalist Club, with Vice-President William Howgate in the chair:

"Mr. Walter Raine then read a series of "Notes on the Birds of the Leeds District," illustrated by specimens. Specimens (all being eggs) were also shown by W. H. Hay."

\section{AT MOOSE JAW, 1891:}

Raine took a holiday in 1891 to collect birds' eggs in western Canada. He was so enthused by what he saw and collected that he spent the winter writing his observations and making his own engravings to illustrate them. He rushed his book, Bird Nesting in Northwest Canada, into print by the next spring and said in his preface: "The book is also intended to be a guide to sportsmen and anglers who intend visiting the territory, and it may even be of some use to intending settlers."14

Raine had arrived 3 June at Port Arthur, Ontario, where Peregrine Falcons had nested on a cliff on nearby Pie Island. On 7 and 8 June he 
collected at Moose Jaw, "a small market town with a population of 600." Raine returned to Moose Jaw for another day, 15 June, on his return trip. Altogether Raine described 39 species he had seen at Moose Jaw, noting the McCown's Longspur as the second commonest species after the "buffalo-bird," the then current name for what is now the cowbird, on the grassy upland plains. The Upland Sandpiper was "exceedingly abundant on the prairies and their eggs are often gathered for food." Raine did not see a single Black-billed Magpie, but was told that they were present in some aspen bluffs north of Regina.

At Moose Jaw, Raine reported nests of the American Bittern, Mallard, Bluewinged Teal, American Wigeon, Northern Shoveler, Swainson's Hawk, Ferruginous Hawk (with three young), Sharp-tailed Grouse, Sora, American Coot, Killdeer, Common Snipe, Longbilled Curlew, Upland Sandpiper, Spotted Sandpiper, Willet, Wilson's Phalarope, Eastern Kingbird (without eggs as yet), Catbird, American Robin, Common Grackle, and Rufous-sided Towhee. He found a Prairie Falcon sitting on a pile of sticks on a ledge in a small cliff along Moose Jaw Creek, without evidence of active nesting. His nest of McCown's Longspur was probably identified correctly, and indeed the McCown's Longspur skins that Raine presented to the Museum of the Geological Survey in Ottawa, the forerunner of the National Museum, were the first for their collection. Raine's supposed nest of the Baird's Sparrow, identified later from the size and appearance of the eggs is much more questionable, though the species was undoubtedly common there before most of the grassland was ploughed. The Redheaded Woodpecker nest with seven eggs, in a hollowed post that stood in water, was a species well known to Raine in Toronto and, if accepted, would be by 89 years the first fully documented nest of this species within the present boundaries of Saskatchewan. Eggs of this species were not in great demand, and Raine should not have been victim of the common error by less knowledgeable observers of giving the name to males of other woodpecker species with a small red cap.

Raine tells us that one of his collectors that year (1891) had taken two sets of five and two eggs on 7 April from Trumpeter Swan nests at Buffalo Pound Lake north of Moose Jaw. The egg measurements given are appropriate and these represent our only documented historic records for Saskatchewan outside of the Cypress Hills. The "Greater Scaup" with young was almost certainly a Lesser Scaup, and the "Rusty Blackbird" nests were equally certainly those of the Brewer's Blackbird. A supposed nest of the Lesser Yellowlegs was almost certainly misidentified.

Raine's companion told of seeing flocks of "nearly a hundred" Eskimo Curlews early in May that year, and of shooting "quite a number" before they moved on north in the second week of May. Although tantalizing, this record cannot be given full credence because the numbers reported seem rather high even for 1891, and because the identification of shorebirds by amateurs has always been fraught with difficulty.

\section{AT RUSH LAKE, 1891:}

Raine moved on almost $100 \mathrm{mi}$. farther west and got off the train at Rush Lake station, where he stayed six days from 9 through 14 June. $^{14}$ Between Moose Jaw and Rush Lake there were "no trees, ... . not even a bush." In 1891, the railway still pursued its original course around the north end of the lake and the little station was along Rushlake Creek, about $2 \mathrm{mi}$. west of the lake. Later, the railway was rebuilt through the lake, so that the present village of Rush Lake is a mile south of where it was at the time of Raine's visits. 


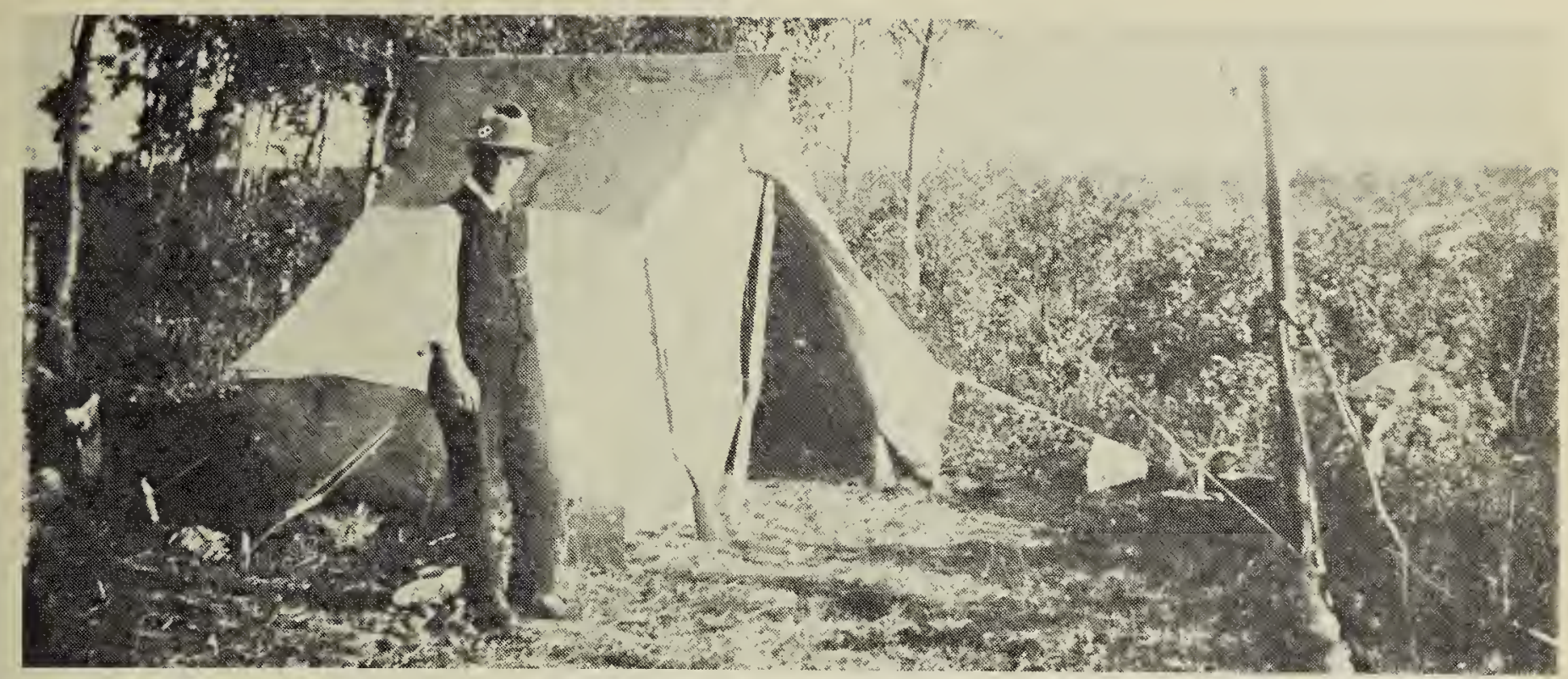

Raine on a collecting trip.

Macdonald, the station agent, told Raine about 50 pairs of White Pelicans that were nesting on a stony sandbar at the eastern extremity of Rush Lake, and Raine could see their white outlines from the distance, but was told that their eggs had already hatched. Here again, the McCown's Longspur was the commonest small bird on the elevated prairies and Raine specifically commented on the absence of the Chestnutcollared Longspur (its later increase may have coincided with heavier grazing and shorter grass).

Raine reported 44 species during his stay. Near the station, he collected egg sets of the Pintail, American Wigeon, Northern Shoveler, Canvasback, Killdeer and Short-eared Owl. On 10 June Raine made a trip $5 \mathrm{mi}$. north to Handsome Lake, where 25 pairs of Avocets were nesting on a stony sandbar on the east side of the lake; Raine collected only the newly laid eggs, sucking their contents to relieve his thirst on a hot day. He collected a clutch of five eggs from a Canada Goose. Macdonald in early May had collected two clutches of Canada Goose eggs from the same site, and placed them under a domestic hen at the station house, anticipating some fine suppers later in the year.
At the northern end of Handsome Lake, Raine made a number of obvious misidentifications. He collected a Northern Phalarope in migration and found two phalarope nests nearby; he incorrectly assumed that one of these nests was that of a Northern Phalarope, although he was surprised to find it breeding so far south.

He and his companion then waded to two small sandy islands, where terns and gulls were nesting in small hollows in the sand. As usual, there were also non-nesting species roosting at the tip of the island; Raine shot three gulls with black heads, identified them as Bonaparte's Gulls, and assumed that they were one of the nesting species.

On 11 June, Mr. Spalding, manager of the Canadian Agricultural Company farm to the west, took Raine $10 \mathrm{mi}$. north to a 4-mi.-long lake "sheltered between the hills." This very likely was Prairie View Lake, which was originally $4 \mathrm{mi}$. long, in an appropriate location, running east and west, but only ever a small fraction of the width of $2 \mathrm{mi}$. stated by Raine. On the way, Raine collected a nest with one egg of what he assumed was the Pallid Horned Lark, the form to be expected in the "Interior of British America" according to the First A.O.U Check-List of 1885. Raine that winter 
sent the specimen to Jonathan Dwight, Jr., who pointed out that it was the Desert Horned Lark. Oologists of those times were anxious to collect a set of each subspecies listed in the CheckList!

Raine collected a Least Sandpiper, a Buff-breasted Sandpiper and another Northern Phalarope and assumed from the time of year that they should be nesting, though, not surprisingly, he could not find their nests. On a sandbar with gull eggs of two sizes, he assumed the nests were Herring and Bonaparte Gull nests, especially when he again shot a "fine adult Bonaparte's Gull" for confirmation. The nests were probably those of California and Ring-billed Gulls.

In a hole in the 20-foot bank of the lake, was a Bufflehead nest with 12 eggs, an unusual but plausible record. Raine mentioned that wherever trees were present, the Bufflehead nests in hollow trees, as at Oak Lake, Manitoba. Raine next found nests of the Longbilled Curlew, Spotted Sandpiper, Willet, and Wilson's Phalarope.

Raine saw Turkey Vultures daily and sketched a supposed nest of this species on the ground, though he made no mention in his text of personally finding such a nest. Raine's Indian guide, John, said that Turkey Vultures had been more numerous in his boyhood, in the days of the buffalo, and that up to 20 or 30 would collect at a buffalo carcass.

On 12 June, John and Raine spent an hour digging down to the seven eggs of a Burrowing Owl, following the burrow vertically for three feet and then horizontally for another four feet. Another day they dug out a coyote den. During his last three days at Rush Lake, Raine reported nests of the Gadwall, Pintail, American Green-winged Teal, Marsh Hawk, Sharp-tailed Grouse, Piping Plover (which he misidentified as the Semipalmated Plover), Long-billed
Curlew, Spotted Sandpiper, Willet, Wilson's Phalarope, Short-eared Owl, Sprague's Pipit, Vesper Sparrow, and McCown's Longspur.

Raine described the Sprague's Pipit as rare and local, and mentioned that he had received one nest from Crescent Lake, no doubt collected by the Baines brothers, on 31 May 1890. Another of his collectors, $15 \mathrm{mi}$. north of Regina, had told Raine that the pipit could be heard "almost anytime early in June, singing and soaring in the sky." Although this species must have been singing above him, almost out of sight, most of the time, Raine was expecting a song similar to that of the European Skylark and, like most observers of that time, failed to learn to identify the pipit by its song. He did not know the song of the Baird's Sparrow, either, and thought it also "rare and local."

Raine also relayed observations at other times of the year made by Macdonald, the station agent, who was a keen hunter and nest-finder. Macdonald informed Raine that "100 geese and ducks a day is considered only a fair bag for one gun, and anyone very enthusiastic might kill three times this number." On 13 June, Macdonald saw a single Whooping Crane flying towards the lake, but Raine missed seeing it.

\section{AT RUSH LAKE, 1893:}

In 1893, Raine returned to Rush Lake for an 8-day visit, from 25 May to 1 June, and again stopped off on his return trip east on 15 and 16 June. His account was published in nine consecutive issues of Nidiologist. ${ }^{16}$

En route, he stopped for 3 days at Oak Lake, Manitoba, where he visited a Whooping Crane nest from which the two eggs had been taken 4 days earlier; Raine located the nearby collector and purchased the remaining unbroken egg for a dollar.

At Rush Lake in May, Raine collected eggs of the Canada Goose, Gadwall, 
Pintail, Northern Shoveler, Scaup (two sets correctly identified as Lesser Scaup and one with slightly larger eggs identified as the Greater Scaup), Sora, American Avocet, Wilson's Phalarope, Ring-billed Gull (now correctly identified for the first time, though the California Gull he still called the Herring Gull), Common Tern (still misidentified as Forster's Tern), Say's Phoebe, Barn Swallow and Cliff Swallow (the last three species now nesting in the stables and cow-sheds), Horned Lark, Western Meadowlark, Red-winged Blackbird, Baird's Sparrow, McCown's Longspur and, for the first time, Chestnut-collared Longspur.

Raine noted a flock of a thousand Semipalmated Sandpipers and on 1 June shot a Red-breasted Nuthatch that he speculated was nesting in a hole in the barn roof. From Jim Sanderson, the half-breed "Government scout," he learned that Sanderson had found a Trumpeter Swan nest with four eggs in 1885 on an island in Sounding Lake (then in the territory of Saskatchewan, but since 1905 in the province of Alberta).

After visiting Crane Lake, Calgary and Banff, Raine stopped off for two days at Rush Lake on 15 and 16 June. He saw seven Turkey Vultures and a Common Raven feeding on the carcass of a horse. He again visited Handsome Lake which he called "Avocet Lake" and found two Long-billed Dowitchers on the island; thinking that this species, too, should be resident he searched in vain for their nest. In addition to the 80 pairs of Horned (?) Grebes now nesting on he lake, he found nests of Gadwall, Pinail, Redhead, Ring-necked Duck (?$\mathrm{CSH}$ ), Lesser Scaup, American Avocet, Wilson's Phalarope, Ring-billed Gull, Common Tern (still called Forster's), and Say's Phoebe.

\section{AT CRANE LAKE, 1893:}

From 2 to 6 June, Raine stayed at the 76" ranch, also operated by the
Canadian Agricultural Company, near the Crane Lake station. ${ }^{16} \mathrm{He}$ spent hours following a pair of Solitary Sandpipers, hoping to find their nest, not realizing that they were merely in migration. He made a trip 4 miles north to the lake of the same name but, although large numbers of White Pelicans were present on the two islands, they apparently had been flooded out that year. He journeyed up Skull Creek, saw a Bald Eagle, and found two nests of the Ferruginous Hawk, one with one downy young, and one with four eggs, as well as Tree Swallows nesting in hollow trees. Other nests reported were those of the Canada Goose, Pintail, American Green-winged Teal, American Wigeon, Canvasback, Common Merganser, Sora, Upland Sandpiper, Wilson's Phalarope, Western Meadowlark, Yellow-headed Blackbird, Savannah Sparrow, Baird's Sparrow and Claycolored Sparrow.

\section{AT REABURN, MANITOBA, 1893:}

On 21 June 1893 at Reaburn, Manitoba on his return trip from Rush Lake, ${ }^{16}$ Raine and his assistant Fred Dippie collected the first authenticated nest and eggs of the Le Conte's Sparrow, confirmed by collection of the adult as it flew from the nest, ${ }^{515}$ Later in Toronto, Raine and Dippie showed their summer specimens to Raine's "friend and neighbour", Ernest Thompson (Seton). Thompson identified a sparrow that Dippie had collected with 2 eggs at Reaburn on 12 June as that of a Nelson's Sharp-tailed Sparrow, also considered a first for this subspecies. ${ }^{15}$ The eggs and study skins for both the Le Conte's and Nelson's Sparrows were deposited in the United States National Museum in Washington.

\section{Attacks on Raine's credibility}

Raine's relationships with $H$. R. Taylor, the editor of Nidiologist, and with his assistant editor, Dr. R. W. Shufeldt, suddenly soured. Raine had been one of their leading contributors, and had 


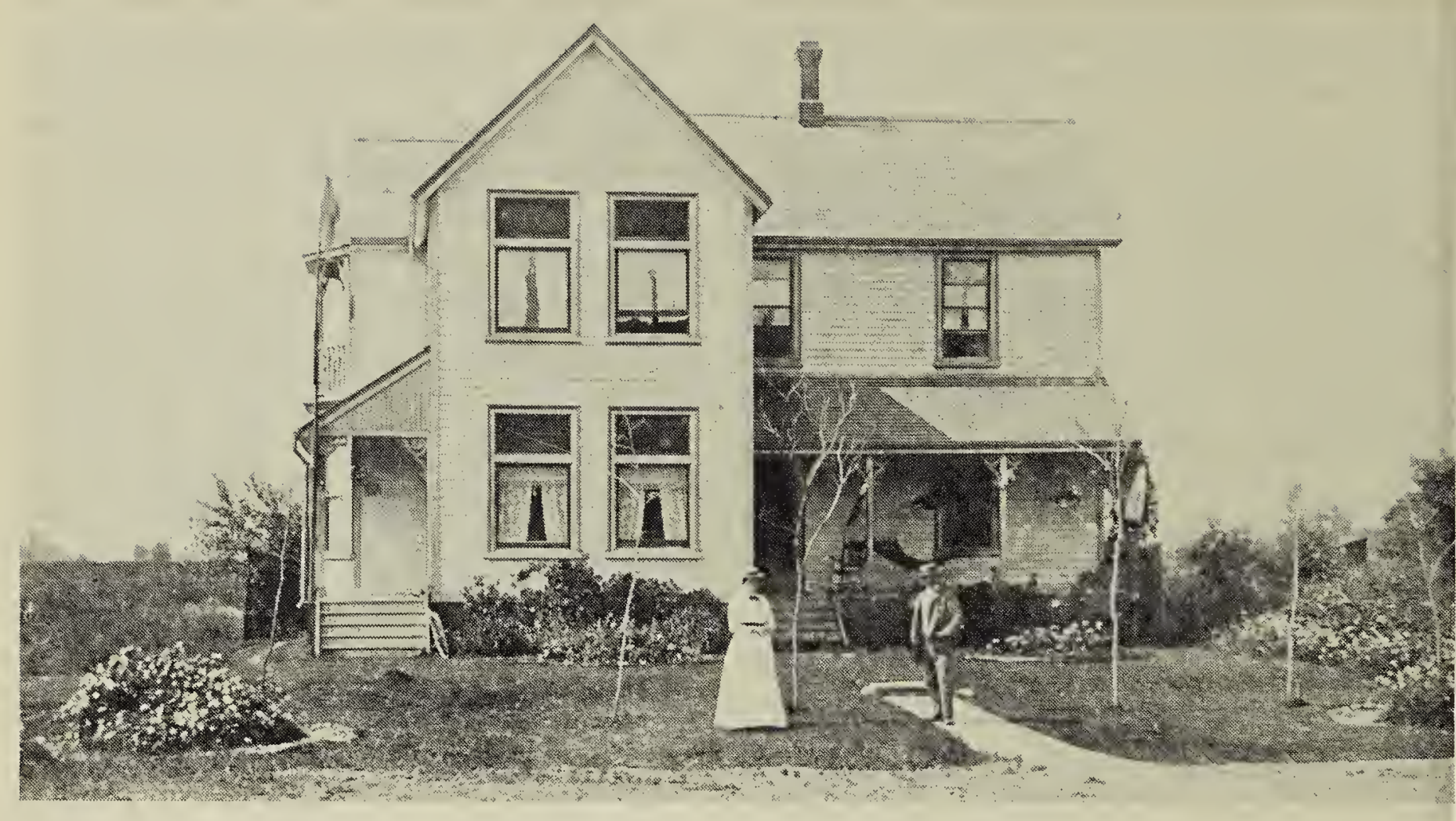

Raines at their home, 50 Waverley St., Toronto.

brought in more new subscriptions than anyone else in a contest in March 1894. Taylor's editorial column in May 1895 accused Raine of taking "singles" from a number of Western Girebe nests and then selling them as "sets" - which Taylor considered "unscrupulous and unworthy of an honest collector." 27

In July 1896, Taylor offered the following snide comment:

"Walter Raine, of Toronto, is announced to have gone to England to dispose of a large collection of eggs. He will be sure to sell."

Taylor then issued the annual index for volume 2 , omitting page numbers for articles by his chief contributor, Walter Raine.

Meanwhile, Major Charles E. Bendire wrote to the Nidiologist to criticize Raine's claim that he had the first set of eggs of the Belted Piping Plover. ${ }^{17}$ Bendire pointed out that the Smithsonian had a set of Piping Plover eggs with parent, "taken by Mr. Donald Gunn of the Hudson Bay Co., ... on the shores of Lake Winnipeg as early as 1862."

Next, under the heading of "Raineism" was a two-page attack on
Raine by Dr. R. W. Shufeldt, a medical doctor and a prolific writer of 1565 papers. Shufeldt atacked Raine for selling eggs of the Black Scoter from Greenland, when Hagerup's The Birds of Greenland failed to even list that species. ${ }^{25}$ Shufeldt also claimed that eggs sold as those of the Little Brown Crane, from Crescent Lake, Assiniboia, and Duck Lake, Saskatchewan, were in fact substituted cheaper eggs of the Demoiselle Crane from Europe. ${ }^{26}$ Furthermore, Shufeldt claimed that the Little Brown Crane did not breed at Duck Lake or Crescent Lake. ${ }^{25}$ (We now know that Saskatchewan specimens are intermediate, ${ }^{30}$ they were described as a new subspecies, Grus canadensis rowani, by Walkinshaw in $1965 ;{ }^{31}$ the measurements of the eggs made by Shufeldt differed trom those given by Raine in his book, but would still fal within the known range of egg sizes for such intermediate individuals.)

Raine replied by offering to bet $\$ 200$ to Taylor or Shufeldt's $\$ 100$ that his eggs were authentic and that cranes dic indeed nest at those localities. ${ }^{18}$

Next, John Macoun wrote to the 
Nidiologist, taking full responsibility for the supposed "sets" of Western Grebe eggs. ${ }^{13}$ Macoun admitted that he "just waded around and collected nearly 100 of the freshest eggs, carried them to my hut and numbered them in sets. ... if there is any fraud in the matter I was the guilty party and not Mr. Raine. . . I I have never known anything against $\mathrm{Mr}$. Raine's character in any sense whatever and many of our rare eggs have been obtained from him."

Raine wrote to complain that since the charges, "my sales of birds' eggs and skins have decreased about onehalf." "13 Raine noted that Oliver Spanner \& Co. had even smaller crane eggs from Alberta, that had not passed through his hands. ${ }^{13}$ Edrick P. Rippon, to whom the Baines brothers had originally sent crane eggs and skins from Crescent Lake, wrote in defense of Raine, telling how he had himself received the two controversial sets from Crescent Lake and sold them to Raine, and that the handwriting Shufeldt claimed was Raine's was in fact Rippon's. ${ }^{24}$ Editor Taylor closed this correspondence by accepting Raine's thinly veiled challenge to a duel ${ }^{19}$ - and chose the eggs of Grus virgo, the Demoiselle Crane, at 10 paces. $^{28}$

\section{Raine's defense}

Raine was not deserted by his friends. R. M. Barnes; who became editor of Oologist, was a staunch supporter. John Macoun used Raine's records in his Catalogue of Canadian Birds, issued in three parts between 1900 and 1904,"11 12 and Reed's North American Birds Eggs in 1904 used Raine records and nine full-page Raine photographs. ${ }^{23}$

Barnes began the October 1910 issue of Oologist with a full-page photo of Mr. and Mrs. Walter Raine, followed on the next page by an effusive eulogy:

"He is one of the best known oologists in all North America and has placed in various collections, perhaps more eggs than any other dealer in North America. The years he has been in the business he has established a reputation for fairness that anyone may well envy. Specimens from him are to be found in almost every leading collection in North America. We have done business with Mr. Raine for practically twenty years and have just recently closed up with him the largest single exchange of specimens we have ever made, aggregating on both sides about 1000 separate specimens."2

It was Raine's expertise that in 1916 corrected O. B. Vandercock's claim to an unusually large clutch of the Barred Owl; Raine pointed out gracefully that the description fitted better the eggs of the Hooded Merganser. ${ }^{29}$ It was Raine's expertise that in 1917 exposed the fraudulent egg selling practices of one Joseph Honacker of the Spokane Public Museum. ${ }^{3}$ When subscribers of the Oologist were asked in 1919 to vote for the three most knowledgeable and reliable oologists in Canada, Walter Raine led the list, followed by R.W. Tufts, Edward Arnold, and ten others. Raine thus maintained the respect of his own fraternity, the oologists.

\section{SURVEY AT RUSH LAKE, 1977}

I felt it would be useful to retrace Raine's steps of 1891 and 1893. John Handbidge, my wife, Mary, and I spent 4 and 5 June 1977 in the Rush Lake area, chiefly at the lakes visited by Raine. Handsome Lake fitted Raine's description exactly, but no longer were there nesting gulls or terns. There were 12 Horned Grebes and 80 Eared Grebes on the lake, suggesting that Raine's 80 nesting pairs of grebes were Eared, not Horned. The Chestnutcollared Longspur was much more common than McCown's on what heavily grazed grassland remained, associated with Sprague's Pipits and Baird's and Vesper Sparrows.

On an alkali lake to the east there were 9 adult Canada Geese with 26 
young, a recent reestablishment after years of absence, 8 Western Grebes, and both Least and Semipalmated Sandpipers. At Prairie View Lake we saw 1 Black Tern, 2 Common Terns, 3 Franklin's Gulls and an American Golden Plover. All three lakes had nests with eggs of Avocet and Canada Goose. The Horned Lark was doing well, as were the Eastern Kingbird, Barn Swallow, Western Meadowlark, Brewer's Blackbird and Savannah Sparrow.

New arrivals to the Rush Lake area since Raine's day included the Blackcrowned Night Heron (with five nests at Handsome Lake), Mourning Dove, Western Kingbird, Black-billed Magpie and Lark Bunting, and the introduced species, the Rock Dove, Common Starling and House Sparrow. The Redtailed Hawk probably also belongs in this list. We also saw Swainson's, Marsh, and Ferruginous Hawks. Numbers of the Common Crow had increased greatly from the early days, but the Turkey Vulture and Common Raven were not to be seen. The once-large lake for which the village of Rush Lake is named, was long ago drained completely by a series of east-west ditches, converting it to cultivated land.

\section{SURVEY AT CRANE LAKE, 1980}

Mary and I spent 5 and 6 June 1980 surveying Crane Lake and its surroundings. The lake was not at all comparable to Raine's time, for it was almost completely dry, apart from a remnant of perhaps a hundred acres of water in the northeast corner of the old lakebed.

\section{Conclusions}

Raine's own errors of identification were certainly understandable. Contemporaries, including John Macoun, made similar mistakes. In their defense, the field glasses of the day were inadequate, there was almost nothing to help identify bird songs, and many species could be identified only from keying out a specimen in the hand. Raine can be excused for thinking that species present in mid-June should be nesting. Standard reference books, even that of Reed more than a decade later, gave erroneous measurements for eggs such as those of the prairie gulls.

Raine's writings still provide interest and pleasure and much worthwhile information. He told a story well, and has left us a vivid record of early visits to productive marshes by an egg collector. There is now a feeling of revulsion towards the "egg-collecting fever" of a century ago, but it must be viewed from a historical perspective. In fact, taken in conjunction with the list of egg prices published in Oologist in $1890,{ }^{9}$ we can see that Raine's trips were profitable in a financial sense.

The lists shows little recompense for collecting and "blowing" the egg of a robin, catbird or Red-winged Blackbird for a retail sale price of $2^{\mathrm{c}}$, but a single egg of the Yellow-headed Blackbird or Tree Swallow was listed at $5^{\natural}$, Sora and American Coot eggs were $10^{\circ}$, Western Meadowlark $12^{\natural}$, Vesper Sparrow,

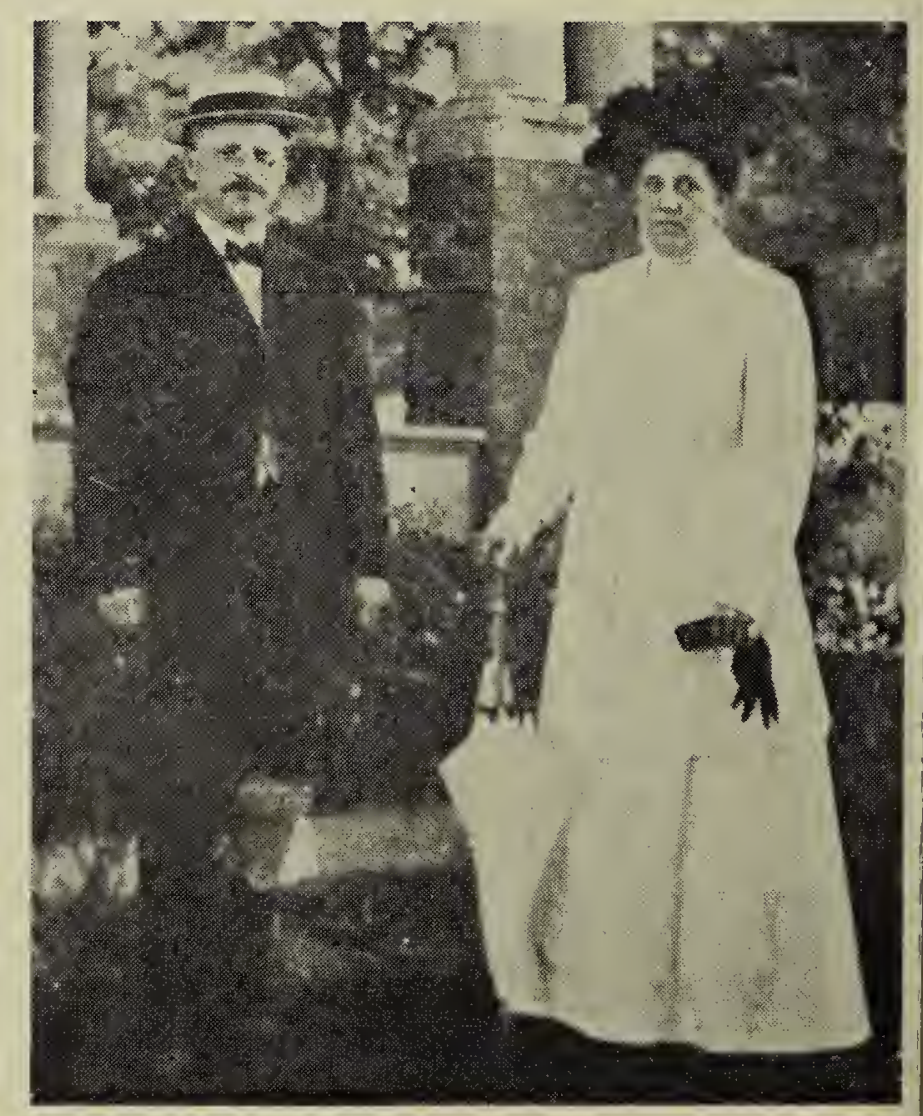

Mr. and Mrs. Walter Raine (1910). 
Forster's Tern and Spotted Sandpiper $15^{\natural}$, Horned Lark 20', Upland Sandpiper, Willet and Clay-colored Sparrow $40^{\circ}$, and Chestnut-collared Longspur, Common Snipe and American Avocet $75^{\circ}$. Eggs of birds of prey and gamebirds seemed to bring higher prices, an evidence of greater demand. One wonders, though, at the work that went into digging out a Burrowing Owl nest when these eggs were rated at $25^{\circ}$, compared to $75^{\circ}$ for Swainson's Hawk and Sharp-tailed Grouse, $\$ 1.25$ for Short-eared Owl, and $\$ 2.00$ for a Ferruginous Hawk or Whooping Crane egg. Even common ducks were priced relatively high with Mallard at $20^{\circ}$, Bluewinged Teal 25`, Northern Shoveler and Gadwall 50`. American Wigeon $75^{\natural}$, Canada Goose $\$ 1.00$ and Canvasback $\$ 1.25$. A full clutch of Canvasback eggs would alone yield more than most men could earn in two days' labour in the city.

In Raine's case, oology was a parttime business as well as a hobby. As a business man, he compounded his errors by selling some incorrectly identified eggs to collectors, including many museums. In addition to errors in his own collecting, as a dealer he purchased eggs from enthusiastic but inexperienced and often youthful collectors in remote areas, and was sometimes too credulous in accepting their identifications. Probably few of his collectors maintained the high standard of accuracy generally evident from specimens collected at Crescent Lake by the Baines brothers.

Although Raine held the confidence of most oologists as he quickly became more knowledgeable, it is nevertheless true that he lost the confidence of many scientific ornithologists. This was probably more because his integrity had once been questioned, than because of the fairly obvious errors of identification he made when he first visited new territory with unfamiliar birds.

Ross D. James of the Royal Ontario
Museum, in a letter of 16 January 1981, told me that although the ROM had purchased 1491 sets of eggs and nests, 500 taken in Canada, from Raine in April 1926, and although on 9 June 1948 Mrs. Stanley F. Raine donated three cabinets and three boxes of eggs and nests, all sets bearing Raine labels were later discarded. Certain other museums may have done the same, following the philosophy expressed by Taverner at the beginning of this article.

Raine unquestionably should not have rushed into print prematurely, documenting his ignorance of the birds in an unfamiliar area. Fortunately, however, most of his errors are obvious, especially to one who has studied the records of Raine's contemporaries and has visited the area where the records were made. I have concluded that Raine's Saskatchewan observations must not be rejected outright. As with any record from that period, each observation should be assessed individually. With appropriate caution, and with a number of substitutions as detailed earlier in this article, a great many useful items of historic interest

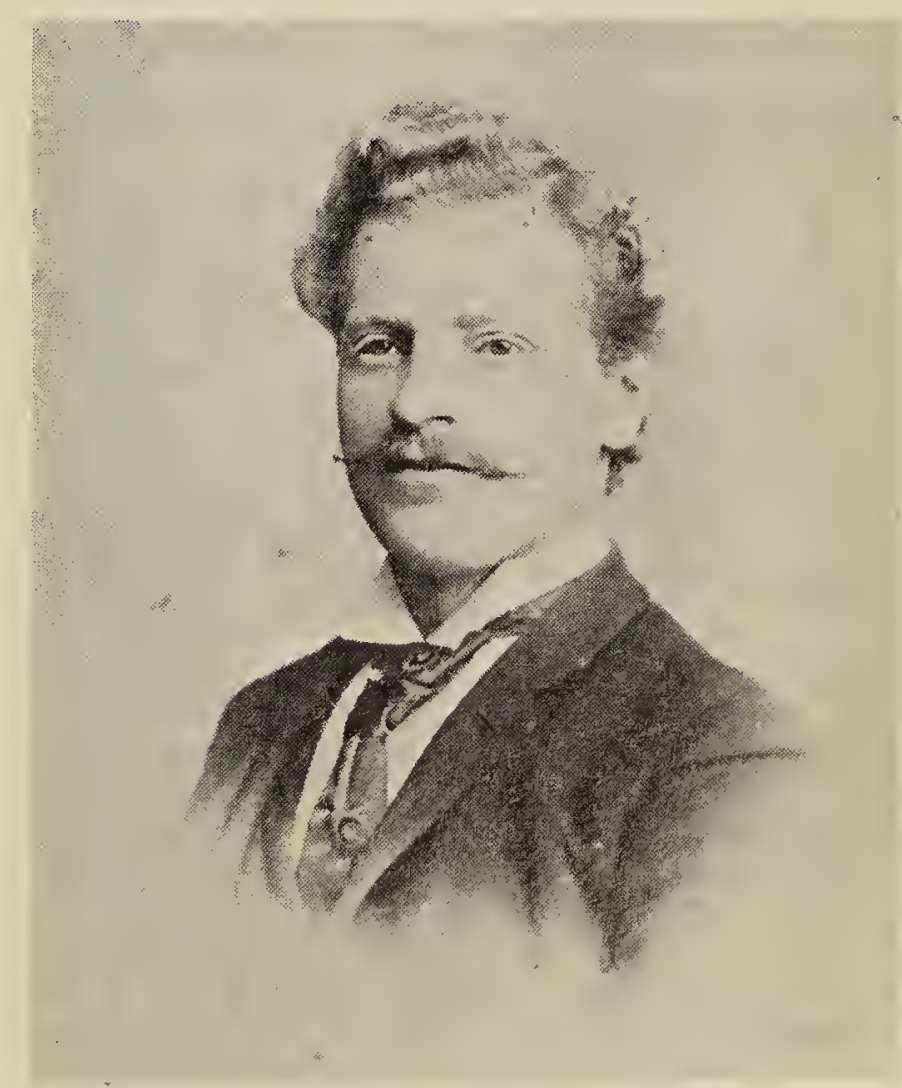

Portrait of Walter Raine - about 1893. 
can thus be salvaged and accepted with reasonable confidence.

\section{Epilogue}

Since Raine's visits in the early 1890 's, most of our native grassland has been ploughed, with a decrease in the numbers of McCown's Longspurs, Baird's Sparrows, Sprague's Pipits, Upland Sandpipers and Long-billed Curlews, to name a few obvious examples. With continuing drainage and diversion of water, we also have fewer sloughs and ponds, and will never again see myriads of waterfowl that were present when the first settlers arrived. Even at the time of Raine's visit, the Trumpeter Swan, Whooping Crane and Sandhill Crane were fast diminishing as nesting birds, and now that the buffalo had gone, the Turkey Vulture and Common Raven were decreasing on the plains.

We can only hope that present intense financial pressures on all Saskatchewan farmers, accelerating the ploughing of further marginal land and the drainage of wetlands, can somehow be checked so that our grassland and marshland birds can be enjoyed for at least another 90 years.

\section{Acknowledgements}

I wish to thank Ross D. James, Associate Curator, Department of Ornithology, Royal Ontario Museum, Toronto, who searched their collection for Raine egg data, and provided electrostatic copies of correspondence between P. A. Taverner and James $L$. Baillie, Jr.; Adrian Norris, Assistant Keeper, Natural History, Leeds City Museum, who provided electrostatic copies of Raine's 17 notes in The Naturalist; K. G. Spencer, John Govett and Arthur Gilpin, who provided assessments of Raine's paper to the Leeds Naturalist Club in 1878; and especially to Mrs. Rupert Warren of Toronto, Raine's granddaughter, who provided photographs, correspondence, the Jourdain reprint, and biographical information. Mary I. Houston helped me throughout all phases of this study.

'BALES, R. B. 1919. The new catalog. Oologist 36:154.

${ }^{2}$ BARNES, R. M. 1910. Walter Raine. Oologist 27:125-126.

${ }^{3}$ BARNES, R. M. 1917. A fraud - Joseph F. Honacker, "U.S. Ornithologist". Oologist 34:168-169.

${ }^{4}$ BENDIRE, C. E. 1896. Eggs of the Belted Piping Plover. Nidiologist 3:106.

${ }^{5}$ DIPPIE, G. F. 1895. Further notes on Leconte's Sparrow. Nidiologist 2:95.

${ }^{6}$ HOUSTON, C.S. 1969. Frank Baines, 1877-1968, a tribute. Blue Jay 27:6263.

${ }^{7}$ HOUSTON, C. S. and A. SCHMIDT. 1981. History of Richardson's Merlin in Saskatchewan. Blue Jay 39:30-37.

8JOURDAIN, F. C. R. 1907. On the eggs of some American Limicolae. Ibis:517518 and plate 11.

${ }^{9}$ LATTIN, F. H. 1889. A complete list of the birds of North America arranged according to the A.O.U. Check List. Oologist 6:213-218.

${ }^{10}$ MACOUN, J. 1900. Catalogue of Canadian Birds. Part I. Ottawa: S. E. Dawson, Queen's Printer. 218 pp.

"MACOUN, J. 1903. Catalogue of Canadian Birds. Part II. Ottawa: S. E. Dawson, Queen's Printer. pp. 219-413.

${ }^{12}$ MACOUN, J. Catalogue of Canadian Birds. Part III. Ottawa: S. E. Dawson, Queen's Printer, pp. 415-733.

${ }^{13}$ MACOUN, J. and W. RAINE. 1896. Raine's crane case. Nidologist 4:23-24.

${ }^{14}$ RAINE, W. 1892. Bird Nesting in North West Canada. Toronto: Hunter Rose. $197 \mathrm{pp}$.

${ }^{15}$ RAINE, W. 1894. Discovery of nests and eggs of Leconte's and Nelson's Sparrows. Nidiologist 1:88-90.

${ }^{16}$ RAINE, W. 1894. Bird-nesting in northwest Canada. Nidiologist 1:67-71; 84-86; 102-106; 117-120; Nidiologist 2:9-10.

${ }^{17}$ RAINE, W. 1896. Eggs of Belted Piping Plover. Oologist 13:40. 
${ }^{18}$ RAINE, W. 1896. Raine bets. Nidologist $4: 11$.

${ }^{9}$ RAINE, W. 1896. An old letter. Nidologist $4: 23$

${ }^{20}$ RAINE, W. 1896. Raine's latest. Nidologist $4: 25$.

${ }^{21}$ RAINE, W. Discovery of the eggs of Solitary Sandpiper. Ottawa Naturalist 18:135138.

${ }^{22}$ RAINE, W. 1904. Discovery of the eggs of Solitary Sandpiper. Oologist 21:164168.

${ }^{23}$ REED, C. A. 1904. North American Birds Eggs. New York: Doubleday, Page. 356 pp.

${ }^{24}$ RIPPON, E. P. From E.P. Rippon. Nidologist 4:24-25.
${ }^{25}$ SHUFELDT, R. W. 1896. Raineism. Nidiologist 3:146-148.

${ }^{26}$ SHUFELDT, R. W. 1896. Raineism - a point in explanation. Nidologist 4:25

${ }^{27}$ TAYLOR, H. R. 1895. "Sets" from "singles" Nidiologist 2:129.

${ }^{28}$ (TAYLOR, H. R.). 1896. "Giving the devil his due" Nidologist 4:27.

${ }^{29}$ (VANDERCOCK, O. B.) 1917. My set of nine Barred Owl's eggs. Oologist 34:3233.

${ }^{30}$ WALKINSHAW, L. H. 1949. The Sandhill Cranes. Cranbrook Institute of Science, Bull. 29. 202 pp.

${ }^{31}$ WALKINSHAW, L. H. 1965. A new Sandhill Crane from central Canada. Can. FieldNat. 79:181-184.

\section{BLACK SCOTER AT INDIAN HEAD, SASKATCHEWAN}

FRED W. LAHRMAN, 7 - 3941 Retallack Street, Regina, Saskatchewan, S4S 3C1 and LORNE SCOTT, P.O. Box 995, Indian Head, Saskatchewan. SOG 2K0

On 11 November 1980 while observing waterfowl on Deep Lake, 7 mi. south of Indian Head, Lorne Scott and I saw an all black diving duck fly low over the water and alight about 450 yards away. With the aid of a $20 \mathrm{X}$ spotting scope we were able to identify it as a Black Scotter. It was in the all black plumage of the adult male but the yellow knob at the base of the bill, while clearly evident, did not have the full brilliant yellow of the male which was seen on Wascana Lake. ${ }^{2}$ On the following day I saw the bird again in the same area but at much closer range. I believe that this is the first record of the species for the Qu'Appelle area covered by "Birds of the Qu'Appelle 1857-1979."'

Other birds observed on the lake at this late date were 125 Whistling Swan, 300 Canada Goose, 3 White-fronted
Goose, 2 Lesser Snow Goose, 1 Black Duck, 25 Northern Shoveler, 1 Redhead, 1 Canvasback, 100+ Lesser Scaup, 75 Common Goldeneye, 50 Bufflehead, 1 White-winged Scoter, 28 Hooded Merganser and 10 Common Merganser. Other late dates were 1 Turkey Vulture 3 November and 100 Sandhill Crane 15 November observed near Indian Head by Lorne Scott. On 23 November he also saw 2 Lesser Snow and 3 White-fronted Geese at Deep Lake.

'CALLIN, E.M. 1980. Birds of the Qu'Appelle, 1857-1979. Sask. Nat. Hist. Soc. Spec. Publ. 13, Regina, Saskatchewan.

${ }^{2}$ KREBA, R. 1980. A black day at Wascana Marsh, Regina. Blue Jay 38(2):120121. 